\title{
"Human Rights" Protection for Corporate Antitrust Defendants: Are We Not Going Overboard?
}

\author{
Albert Sanchez-Graells \\ Senior Lecturer, University of Leicester
}

Francisco Marcos

Professor of Law, IE Law School

\section{Abstract:}

There seems to be a clear trend of increased protection of 'corporate human rights' and, more specifically, due process rights (or procedural fairness) in the field of enforcement of competition law. To a large extent, that trend is based on the uncritical extension of human rights protection to corporate defendants by a process of simple assimilation of corporate and individual defendants. This paper briefly explores the rationale behind the creation of due process rights when the individual is the beneficiary of such protection. It then goes on to critically assess if the same need exists for the extension of those protections to corporate defendants, particularly in the field of competition law or antitrust enforcement. It concludes with some warnings concerning the diminishing effectiveness of competition law prohibitions and of human law protection that can result from an overstretched conception of due process protection in this area of EU economic law.

From a substantive perspective, the paper submits that the extension of human rights to corporations cannot be uncritical and should not be completely symmetrical to that for human beings; but that it rather needs to be necessarily adapted to their circumstances. To put it more bluntly, it is suggested that in the field of the enforcement of economic law, administrative law procedures should be sound and there should clearly be a strong system of judicial review in place, but corporations should not have access to broader constitutional or human rights protections and any perceived shortcomings in the design and application of those procedures should remain within the sphere of regulatory reform.

Keywords: Due process, procedural fairness, good administration, corporate human rights, human rights, competition law, antitrust law, enforcement, effectiveness 
This text may be downloaded for personal research purposes only. Any additional reproduction for other purposes, whether in hard copy or electronically, requires the consent of the author(s). If cited or quoted, reference should be made to the following:

A. Sanchez-Graells, F. Marcos, "Human Rights" Protection for Corporate Antitrust Defendants:

Are We Not Going Overboard?, University of Leicester School of Law Research Paper No. 14-03.

(c) 2014 Albert Sanchez-Graells, Francisco Marcos

University of Leicester School of Law Legal Studies Research Paper Series 


\title{
"Human Rights" Protection for Corporate Antitrust Defendants: Are We Not Going Overboard?
}

\author{
Albert Sanchez Graells ${ }^{*}$ and Francisco Marcos ${ }^{\dagger}$ \\ Prepared for the $9^{\text {th }}$ ASCOLA Conference on "Procedural Fairness in Competition Proceedings" to be \\ held at the Centre for Antitrust and Regulatory Studies, University of Warsaw, 26-28 June 2014.
}

\begin{abstract}
Draft as 30 January 2014, please do not
quote without authorial permission
\end{abstract}

\begin{abstract}
There seems to be a clear trend of increased protection of 'corporate human rights' and, more specifically, due process rights (or procedural fairness) in the field of enforcement of competition law. To a large extent, that trend is based on the uncritical extension of human rights protection to corporate defendants by a process of simple assimilation of corporate and individual defendants. This paper briefly explores the rationale behind the creation of due process rights when the individual is the beneficiary of such protection. It then goes on to critically assess if the same need exists for the extension of those protections to corporate defendants, particularly in the field of competition law or antitrust enforcement. It concludes with some warnings concerning the diminishing effectiveness of competition law prohibitions and of human law protection that can result from an overstretched conception of due process protection in this area of EU economic law.

From a substantive perspective, the paper submits that the extension of human rights to corporations cannot be uncritical and should not be completely symmetrical to that for human beings; but that it rather needs to be necessarily adapted to their circumstances. To put it more bluntly, it is suggested that in the field of the enforcement of economic law, administrative law procedures should be sound and there should clearly be a strong system of judicial review in place, but corporations should not have access to broader constitutional or human rights protections and any perceived shortcomings in the design and application of those procedures should remain within the sphere of regulatory reform.
\end{abstract}

\section{KEYWORDS}

Due process, procedural fairness, good administration, corporate human rights, human rights, competition law, antitrust law, enforcement, effectiveness.

\section{JEL CODES}

$\mathrm{K} 21, \mathrm{~K} 23, \mathrm{~K} 42$.

\footnotetext{
* Senior Lecturer in Commercial Law, School of Law, University of Leicester. a.sanchez-graells@le.ac.uk.

+ Professor of Law, IE Law School. francisco.marcos@ie.edu.
} 
"What we now face is the danger to human rights future presented by the genesis of a corporation-friendly human rights legal sensibility." A Grear, Redirecting Human Rights (2010)

\section{INTRODUCTION}

Despite having originally been recognised with the clear (and limited) purpose of protecting the individual from State abuses (and, incidentally, from violations by other individuals where their rights may clash), ${ }^{1}$ the human rights recognised in the European Convention on Human Rights $(E C H R)^{2}$ have been, to a significant degree, extended to protect corporate entities. ${ }^{3}$ As the European Court of Human Rights (ECtHR) put it, the assumption underlying such a protective stretch is that the dynamic nature of the ECHR (ie its perception as a 'living instrument') and an unspecified set of 'present-day conditions' supported a (very) flexible interpretation of the ECHR with the teleological aim of making corporations the beneficiaries of an array of 'human rights'. ${ }^{4}$ For the purposes of this paper, the focus should be on the extension of due process rights to corporate defendants-ie mainly Article 6(1) of the ECHR and, more specifically, in the field of competition law enforcement.

It is important to stress from the beginning that, in our view, the extension of such protection has not been homogeneous or derived from a clearly defined strategy or conscious decision to actually grant such protection to corporations, and that the patchy developments in this area have usually derived from a compartmentalised or 'siloistic' approach to the analysis of specific problems in given cases. Under the very specific circumstances of those cases, good administration considerations (or, to some extent, the will to limit public administrative intervention in the context of enforcement of economic law) were usually the real underpinning rationale for the decisions reached by the Courts confronted with 'corporate human rights' claims (mainly, the ECtHR and the Court of Justice of the European Union, CJEU), but were however cloaked under human rights rhetoric. Such 'incremental' (creeping) extensions of 'corporate human rights' protection have resulted in a broader trend were there seems to be a full assimilation between individual human rights (and human rights of groups and associations concerned with the promotion of activities mainly centred in the individual) and 'corporate human rights' (or rights of corporate entities, including or particularly concerned with those engaged in for-profit and economic activities). In our view, the creation of such momentum for 'corporate human rights' has been accidental (and unfortunate). And all of this justifies a reassessment of the situation before it continues to develop.

\footnotetext{
${ }^{1}$ See J Nickel, 'Human Rights', in EN Zalta (ed) The Stanford Encyclopedia of Philosophy (Summer 2013 Edition), plato.stanford.edu/archives/sum2013/entries/rights-human/.

2 Convention for the Protection of Human Rights and Fundamental Freedoms, Rome, 4.XI.1950, echr.coe.int/Documents/Convention_ENG.pdf.

${ }_{3}^{3}$ For a general overview, see M Emberland, The Human Rights of Companies. Exploring the Structure of ECHR Protection (Oxford, OUP, 2006) 4, clearly indicating that 'under the Convention the notion of companies enjoying rights protection is not disputed in principle: The Court does not per se regard corporate litigation with suspicion'. See also U Baxi, The Future of Human Rights, 3rd edn (Oxford, OUP, 2012).

${ }^{4}$ In the case at hand, the right to 'private and family life': Société Colas Est v France (2004) 39 EHRR 17. This case and its rationale is rightly criticised by $\mathrm{C}$ Harding, $\mathrm{U}$ Kohl and N Salmon, Human Rights in the Market Place: The Exploitation of Rights Protection by Economic Actors (Aldershot, Ashgate, 2008) 28. For more commentary, see 'Roquette Freres, ECJ Case C-94/00' (2003) Columbian Journal of European Law 10: 137, and the discussion in Emberland, The Human Rights of Companies (n 3) 132 and ff.
} 
Generally, the extension of 'human rights' protection to corporate entities is an accepted trend (even more so, one strongly supported by practising lawyers and corporate defendants) and only very limited voices question such an expansion of the scope of application of human rights instruments (which is seen as a legal refinement or an expression of 'legal finesse' against which it is at least politically incorrect to argue). Most studies in the field avoid the fiendish question of the ultimate justification for the extension of human rights protection to corporations (and, more specifically, to corporate antitrust defendants) and focus on the technical analysis of the contours of such protection. Such a 'minimalistic' approach to these issues side-tracks the key discussion that, in our opinion, needs to be had (since, otherwise, we can't see the forest for the trees). Others offer a rather weak justification based on very general principles that merely result in a desiderata and, even then, simply acknowledge that 'corporate human rights' protection should be weaker, without clearly indicating why or how weak, or why those reasons would not justify a complete suppression of such protection for corporate entities. ${ }^{5}$ Still others start arguments against the existence of the protection itself, but fall short from justifying its complete suppression ${ }^{6}$ or, in the alternative, look for alternative reasons for extending the protection to corporations. ${ }^{7}$ These intermediate positions may derive from the problematic assumption that, in the absence of human rights protection, corporate defendants may not have resort to any other devices to prevent abuses of power committed by the competition authorities. However, a realistic approach towards the system for the enforcement of competition law (at least in the EU and in other jurisdictions) and the administrative procedures underpinning it clearly shows that this is not the case. Competition enforcement procedures do provide corporate defendants with a sufficient degree of protection of their core interests and include systems of checks and balances (including judicial review) that prevent (at least most) instances of abuse of public power. Therefore, such intermediate positions may need reviewing; at least if a more definitive answer is attempted to the extant question of 'how weak, if any, should corporate human rights protection be'? ${ }^{8}$

\footnotetext{
${ }^{5}$ Recently, for instance, Andreangeli has indicated that: "extending some of the Convention [on Human Rights] guarantees to private enterprises affected by the operation of regulatory structures, including that for the application of competition law, is clearly consistent with an objective concept of the rule of law, according to which 'everyone' should be protected from the arbitrary and excessive exercise of public power. Although it was accepted that the intensity of this protection may be 'weaker' than that applied to natural persons, it was therefore argued that commercial actors should enjoy some basic guarantees such as the right to a fair trial", see A Andreangeli, 'The public enforcement of Articles 101 and 102 TFEU under Council Regulation 1/2003: due process considerations', in I. Lianos \& D Gerardin, Handbook of European Competition Law. Enforcement and Procedure (Cheltenham-Norhampton, Edward Elgar, 2013) 138-180, at 142.

${ }^{6}$ For instance, MacCulloch has indicated that "for the analogous extension of the privilege [against selfincrimination] from a 'human' right into a true 'legal' right, which might be enjoyed by legal, as well as natural, persons, there needs to be much fuller justification of that right", A MacCulloch, 'The privilege against selfincrimination in competition investigations: theoretical foundations and practical implications' (2006) Legal Studies 26(2): 211-237, 234.

${ }^{7}$ Precisely in the competition law enforcement (investigation) settings, although the underlying idea is present in the dynamic interpretation of the ECtHR (protection against arbitrary interferences of public authorities), see M Emberland, 'Protection Against Unwarranted Searches and Seizures of Corporate Premises under article 8 of the European Convention of Human Rights: The Colas Est SA v. France Approach' (2003) Michigan Journal of International Law 25: 77-116, 92-93 (concerning corporate privacy protection according to article 8 ECHR).

${ }^{8}$ At this point, it should be acknowledged that one of the authors adopted a similarly intermediate position recently, by indicating that his work was premised in "the express normative assumption that undertakings (or companies) deserve a relatively more limited protection than individuals under the ECHR and, more specifically, under Article 6(1) ECHR-at least as regards non-core due process guarantees, such as the standard of review
} 
Nonetheless, there are more definitely opposed voices, and some recent studies convincingly make the case for a thorough reassessment of the uncritical assumption of the existence of 'corporate human rights'. ${ }^{9}$ In our view, the very weak logical foundations supporting the existence of 'corporate human rights' as such and the very strong normative assumptions required to accept this legal development make it ripe for discussion.

This paper aims to contribute to such a debate in the specific field of competition law enforcement, where the expansion of 'corporate human rights' protection is causing significant distortions of the existing enforcement mechanisms ${ }^{10}$ and diminishing (or, at least, threatening to diminish) the effectiveness of rules aimed at curving anticompetitive behaviour. Indeed, the extent to which 'corporate human rights' and, more specifically, due process rights affect competition law enforcement has been gaining relevance and attracting more and more attention in the European Union (EU), particularly in the wake of its accession to the ECHR. ${ }^{11}$ However, this discussion has been running in parallel to the more critical assessments of the extent to which corporate entities should be afforded 'human rights' protection at all, ${ }^{12}$ and has remained relatively isolated. In the end, though, it seems that resolving specific issues in the competition enforcement field would benefit from a clearer link to the more general discussion.

This paper attempts to establish such a link by briefly exploring the rationale behind the creation of due process rights when the individual is the beneficiary of such protection ( $\$ 2)$. The analysis then goes on to critically assess if the same need exists for the extension of those protections to corporate defendants, particularly in the field of competition law or antitrust enforcement (§3). It finishes with some warnings concerning the diminishing effectiveness of competition law prohibitions and of human law protection that can result from an overstretched conception of due process protection in this area of EU law (\$4). An overall conclusion is also provided (§5).

applicable to the revision of competition law decisions (as opposed to 'core' due process guarantees such as the presumption of innocence, the principle of equality of arms, the right to have full access to the evidence, or the right not to suffer undue delays", A Sanchez Graells, "The EU's Accession to the ECHR and Due Process Rights in EU Competition Law Matters: Nothing New Under the Sun?', in V Kosta, N Skoutaris \& V Tzevelekos (eds), The Accession of the EU to the ECHR (Oxford, Hart Publishing) 2014, forthcoming (available at: http://ssrn.com/abstract=2156904). This paper goes beyond that assumption or, at least, engages in some further depth in the reasons for such a proposal-which may well support a further restriction of 'corporate human rights' protection than previously advocated for.

${ }^{9}$ Of particular interest, despite being concerned with more general philosophical issues, A Grear, Redirecting Human Rights. Facing the Challenge of Corporate Legal Humanity (Basingstoke, Palgrave MacMillan, 2010).

${ }^{10}$ This is plain to see where, even in the field of 'soft' or 'pre' enforcement mechanisms such as market enquiries, the (aggressive) extension of a 'corporate human right' to due process can trump the most generic of information gathering and preliminary assessments made by competition authorities. For instance, see the UK Competition Appeals Tribunal Judgment of 2 October 2013 in BMI Healthcare Limited v Competition Commission (No. 1) [2013] CAT 24 and its discussion in A Sanchez Graells, 'UK's Competition Commission findings on private healthcare markets unfair, says UK CAT', How to Crack a Nut, 7 October 2013, howtocrackanut.blogspot.co.uk/2013/10/uks-competition-commission-findings-on.html.

${ }^{11}$ For general discussion, see Sanchez Graells, 'The EU's Accession to the ECHR and Due Process Rights in EU Competition Law Matters: Nothing New Under the Sun?' (n 8).

${ }^{12}$ See, for instance, Ch 2 'The Sun, Liverpudlians and "The Truth": A Corporate Right to Human Rights?' in Harding, Kohl \& Salmon, Human Rights in the Market Place (n 4) 23-52; and H Paul, 'Corporations are not human, so why should they have human rights?' EcoNexus, September 2011, econexus.info/publication/corporations-are-not-human-so-why-should-they-have-human-rights. 


\section{HUMAN RIGHTS PROTECTION AND DUE PROCESS GUARANTEES FOR INDIVIDUALS: WHEN IT ALL MADE SENSE}

Human rights recognition is rooted in providing individuals a set of legal and political claims concerning their personal and collective living conditions. In the original core of human rights, guarantees were concerned with ensuring acceptable living conditions leading to self-development, free from unjustified interference or imposition by third persons or the State itself. Further developments (or second generation human rights) are concerned with promoting a higher standard of living that strengthens the possibilities for such self-development, whereas the most recent (third generation) developments exceed the sphere of the individual (even in its social context) and try to tackle issues concerned with the environment and other intangible realities (such as governance or promotion of peace). ${ }^{13}$ Indeed, a distinction should be drawn among different types of human rights, as several different classes of rights are bundled together under this broad heading. The original "rights of man" recognized by the XVIII century declarations concerned mainly personal liberty and political freedom. They are negative or basic rights aimed at protecting individuals from government actions (liberty, security, participation). Some of them concerning interpersonal relations among individuals (association, meeting), related to their cohabitation and organization and the opportunities people might seek. On the other hand, there are also aspirational or positive (welfare) rights, also called "second generation" rights (e.g. education, health care) that demand a positive action by the government to promote and guarantee them in practice. Our discussion will mainly be concerned with negative or basic rights, as they encompass due process rights.

In general, (core, first generation) human rights guarantees introduce restraints to State and other individuals' behaviour as a way of constructing a sphere of personal freedom and protection. At the root of all human rights (particularly first generation) there is a powerful ethical claim (of political significance, of course), which has strong juridical implications by giving individuals legal entitlements. It suffices to say for our purposes that almost every modern legal system recognizes individuals a set of rights that can be enforced and made effective towards the State. The ultimate objective of such protections can indeed be found in 'values such as democracy, the rule of law and personal freedom, which inspired the drafting of human rights' catalogues such as the ECHR itself'. ${ }^{14}$

Although there are a variety of human rights, they are mostly closely linked to the human condition of their subject matter. The physical embodiment of human rights in persons or individuals is a crucial and central feature present in their creation and recognition. In the end, it is the vulnerability and weakness of living human beings (in relation to their life, their integrity, their dignity, their freedom) that explains why they were created and how they were recognized. ${ }^{15}$ Shielding individuals from abuses committed by the public powers was at the root of human rights. ${ }^{16}$ In their more blatant version, it is the frailty of life and the integrity of human beings, their protection against physical and psychological suffering or death unjustly caused by the State that is present as a foundation of human rights. A similar rationale can be extended concerning the

\footnotetext{
${ }^{13} \mathrm{C}$ Tomuschat, Human Rights. Between Idealism and Realism, 2nd edn (Oxford, OUP, 2008) 25-69.

${ }^{14}$ Andreangeli, 'The public enforcement of Articles 101 and 102 TFEU under Regulation 1/2003' (n 5) 142.

${ }^{15}$ See A Grear, 'Human Rights-Human Bodies? Some Reflections on Corporate Human Rights Distortion, the legal subject, embodiment and Human Rights Theory' (2006) Law Critique 17(1): 171-199, 194-195.

${ }^{16}$ M Dan-Cohen, Rights, Persons and Organizations (Berkeley, U California Press) 1986, 85-87.
} 
protection of dignity, identity, equality and freedom of individuals. For that very reason, most human rights "make no conceptual sense without presupposing a vulnerable living body". ${ }^{17}$

In the particular case of due process rights, it is worth stressing that they were originally conceived as a protection for natural human beings when criminally prosecuted. In their original conception, due process rights are rooted in the emotional condition embodied in individuals, which deserved respectful treatment in criminal prosecutions (habeas corpus). This feature of due process is clearly present in their old-time configuration as the right of individuals to be notified of the charges against them, as well as their right to a fair hearing. ${ }^{18}$ Nowadays, in their current formulation as a procedural guarantee (leaving aside the substantive implications/limits regarding various forms of governmental intervention it may have), due process refers to the right to a fair trial, as article 6(1) ECHR sets a requirement for "fair and public hearing within a reasonable time by an independent tribunal established by law". Although its derivations and manifestations may be many, in general, it establishes a framework of procedural safeguards in relation to criminal law enforcement. The applicability of the due process guarantees extend in a limited form to noncriminal investigations under certain conditions. Summarily, these guarantees grant protection both during government investigations of law violations and, afterwards, against government decisions imposing sanctions or liability.

There are several rights bundled together in the right to a fair trial. At its core, it implies the right to be treated fairly and have a fighting chance when facing legal action. Thus, due process would include the presumption of innocence, the principle of equality of arms, the right to have full access to evidence, the right to a fair hearing, the right against self-incrimination, the right to a reasoned decision and the right not to suffer undue delays. As a natural extension of those procedural guarantees, nowadays due process includes also rights concerning evidence and the standard of review of government decisions imposing fines or liability. In practice, from the perspective of government, due process introduces a restraint to judicial and administrative powers, which are required to treat fairly their citizens in criminal proceedings against them.

The underlying justifications of these procedural guarantees are several. Initially, and regarding the factual conditions in which government powers are exercised, they are closely linked to the human condition of those individuals subject to government action. Therefore, it is rooted in individual citizens' weakness (physical and emotional) and their need for protection against potential coercion or abuses by mighty governmental powers. Decisions and sanctions in criminal proceedings also carry with them a stigma that taxes heavily on individual persons. Finally, on a purely juridical

\footnotetext{
${ }^{17}$ Id. 195.

${ }^{18}$ See chapter 39 of Magna Carta, King John promising "[n]o free man shall be taken or imprisoned or disseized or exiled or in any way destroyed, nor will we go upon him nor send upon him, except by the lawful judgment of his peers or by the law of the land". See W. McKechnie, Magna Carta-A Commentary on the Great Charter of King John 375-95 (Glasgow, 2d rev. ed. 1914). Later on the chapter became chapter 29 in the Third Reissue of Henry III in 1225 (Id. at 504, and see 139-59). As expanded, it read: "No free man shall be taken or imprisoned or deprived of his freehold or his liberties or free customs, or outlawed or exiled, or in any manner destroyed, nor shall we come upon him or send against him, except by a legal judgment of his peers or by the law of the land." See also J. Holt, Magna Carta 226-29 (Cambridge: 1965), and Larry May, Global Justice and Due Process, Cambridge, Cambridge University Press, 2011.
} 
dimension, aside from the principle of legality, due process also introduces considerations of justice and fairness that government actions must respect.

As this very cursory account has tried to highlight, due process rights were created to protect the individual in situations where it was particularly vulnerable and exposed to the full and unmatched power of the State trying to impose criminal liability and, consequently, to severely restrict (or suppress) some or all of the individual's liberties and rights. Therefore, they were designed to create a very strong counterbalance to public power and to reassure the individual (and society at large) that the exercise of that power met high standards of justice and fairness. Ultimately, it was the great unbalance of powers and the very severe consequences the individual being prosecuted was facing that justified the creation of those rights. Such justification can hardly be disputed, but it must be stressed that the premises underlying the guarantees need to be present for human rights protection (and due process rights in particular) to continue making sense.

However, these same reasons do not apply (either at all, or to the same extent) when corporate defendants' situation is analysed. As we have seen, human rights were created and recognized as inherent to natural persons, they were not designed with artificial entities (corporations and other legal forms) in mind. Indeed, the essence of corporations is that conceptually, according to the law, they are rights-holding entities. As functioning businesses, they bear the rights granted by law. By law, corporations are legal persons, but corporate personality is a fiction: legally they are treated as if they were persons, but factually they are not. ${ }^{19}$ Nevertheless, conventionally it has become the rule in many legal systems to extend to corporations most of the human rights granted to individual persons (and this trend has been paralleled by the simultaneous imposition to corporations of human rights obligations and liabilities for their violations). ${ }^{20}$ Although theoretically it is not feasible (neither reasonable, at first sight) to recognize some human rights strongly linked to the human condition (e.g. the right to life ${ }^{21}$, sometimes the extension has occurred uncritically, giving way to rather unimaginable arguments and situations. ${ }^{22}$ In our view, such an extension of rights needs to be criticised for several reasons.

To begin with, the frailty and weakness of the individual are (almost) completely absent when corporations are subjected to governmental intervention (with the only possible extension of indirect effects for their managers or owners which, at any rate, are diminished and usually only concerned with the economic implications of those investigations). Secondly, corporations tend to

\footnotetext{
${ }^{19}$ See T Hartmann, Unequal Protection: The Rise of Corporate Dominance and the Theft of Human Rights, 2nd Ed (Berrett-Koehler) 2010, 10 ("The modern corporation is neither male nor female, doesn't breathe or eat, can't be enslaved, can't give birth, can live forever, doesn't fear prison, and can't be executed if found guilty of misdoings. It can cut off parts of itself and turn them into new "persons," can change its identity in a day, and can have simultaneous residences in many different nations. It is not a human but a creation of humans").

20 See P T Muchlinski, 'Human Rights and multinationals: is there a problem?' (2001) International Affairs 77(1): 31-47, and S Deva, Regulating Corporate Human Rights Violations. Humanizing Business, Routledge 2012.

${ }^{21}$ See L J Dhooge, 'Human Rights for Transnational Corporations', Journal of Transnational Law \& Policy (2007) 16(2): 197-250, 239. But see W Van den Muijsenbergh \& S Rezai, 'Corporations and the European Convention on Human Rights' (2012) Global Business \& Development Law Journal 25: 43-68, 51 \& 59-60.

22 See, e.g., concerning the corporations' right to religious liberty in the U.S., R Schragger \& M Schwartzman, 'Some Realism about Corporate Rights' (Nov. 1, 2013) Virginia Public Law and Legal Theory Research Paper No. 2013-43 (available at SSRN: http://ssrn.com/abstract=2360309). On the other hand, in Citizens United v. FEC, 558 U.S. 310 (2010) the U.S. Supreme Court confirmed the free speech rights of corporations.
} 
be in a much more balanced position vis-à-vis public authorities (particularly larger corporations, which are the ones generally concerned with competition law investigations, at least at the EU level). ${ }^{23}$ Finally, the consequences that corporations face are usually of a purely economic or financial nature and, without dismissing their relevance altogether, it is also our view that protection of such economic interests ranks second to the protection of individual freedom or other rights more closely related to the individual's conscience and personality (at least from a human rights protection perspective). In the end, as has been clearly stressed, the rationale behind the granting of human rights to corporations is different than that concerned with their assignment to individuals:

Clearly there is room for arguing that large publicly traded companies have assumed a position of power in all spheres of life comparable to the power traditionally exercised by States, simply through being less amenable to that State power. Thus, on balance, in view of the relative de facto power of companies, it would seem more appropriate to treat them like a State rather than like an individual within the human rights framework, that is, give them obligations but no rights. ${ }^{24}$

Moreover,

Politically, the company is the vehicle for, and embodiment of, capitalism; giving it human rights strongly protects trade, profit and property and reinforces the market economy-often at the expense of other interests, such as those of workers, consumer interests and civil society. Whatever may be the actual reasons behind corporate human rights, jurisprudentially it is difficult to justify them (emphasis added). ${ }^{25}$

Regardless of such lack of ethical and jurisprudential support, the extension of rights has oftentimes come from the application of more specific and apparently technical reasons, which have followed a more restricted logical and normative path and, consequently, arrived at the almost full extension of 'corporate human rights' in a rather uncritical manner. In the case of the rights and freedoms recognized by the ECHR, the broad scope of application of the Convention (article 1) led the ECtHR to extend its protection to corporations since the very beginning. ${ }^{26}$

It is clear however, that corporate persons are not morally equivalent to individuals, ${ }^{27}$ so there should be limits in the increasing legal anthropomorphism of extending human rights to corporations. ${ }^{28}$ The so-called process of "gradual humanization of corporations" ${ }^{29}$ by the ECtHR

\footnotetext{
${ }^{23}$ See L J Dhooge, 'Human Rights for Transnational Corporations' (n21) 242 (“corporations are far better equipped to resist state coercion[, a]lthough owing their continuing existence to the state, corporations possess greater financial resources and access to influential decision-makers that may blunt the power of government, factors which may not be as readily available to their human counterparts").

${ }^{24}$ Harding, Kohl \& Salmon, Human Rights in the Market Place (n 4) 50. See also S R Ratner, 'Corporations and Human Rights: A Theory of Legal Responsibility', (2001) Yale Law Journal 111: 443:545.

${ }^{25}$ Harding, Kohl \& Salmon, Human Rights in the Market Place (n 4) 45 (footnote omitted). See also A Grear, 'Challenging Corporate "Humanity": Legal Disembodiment, Embodiment and Human Rights' (2007) Human Rights Law Review 7(3): 511-543, 534.

${ }^{26}$ Sunday Times v. United Kingdom, 30 Eur. Ct. H.R. (ser. A) (1979).

${ }^{27}$ See critically Grear, 'Human Rights-Human Bodies? Some Reflections on Corporate Human Rights Distortion, the legal subject, embodiment and Human Rights Theory' (2006) Law Critique 17(1): 171-199, 188-189.

${ }^{28}$ But see Van den Muijsenbergh \& S Rezai (n16) 60 ("It may not be too far-fetched to assume that the Court's dynamic (snowballing) humanization of corporations, combined with possible future corporate demands, will in due time allow corporations to also enjoy a right to life"),

${ }^{29}$ Van den Muijsenbergh \& S Rezai (n16) 59.
} 
should not be too broad, but keep in mind both that corporations are dis-embodied entities and the context in which rights and protection claims are raised. The lack of formalism and flexible approach the ECtHR has followed in extending to corporations protections and safeguards initially designed to corporations cannot (artificially) ignore the reality of the corporate form and how it is different from human beings (and that necessarily affects and conditions what rights are recognized to corporations and how). Just as the ECtHR has been willing to pierce the corporate veil, overcoming the fiction of the corporate form, allowing shareholders instead to file claims for ECHR violations, ${ }^{30}$ the ECtHR should consider the singularities of corporations in extending human rights' recognition to them. Likewise, disregarding the corporate personality to protect its shareholders lies at the foundation of granting and extending human rights to corporations in the U.S., ${ }^{31}$ but that logic cannot be applied without limits. Therefore, in our opinion, the recognition of human rights to corporations needs to at least be qualified, not only considering their lack of human features (which is at the basis of many human rights) ${ }^{32}$, but also the context in which potential claims might occur. The extension of human rights to corporations cannot be uncritical and should not be completely symmetrical to that for human beings; ${ }^{33}$ it necessarily needs to be adapted to their circumstances.

Besides, the nature of the procedures in which corporate claims of ECHR violations are raised should also be crucial. The values and principles affected by those roles and proceedings must be taken into account, ${ }^{34}$ and that necessarily leads to tailoring in their application. Among the several rights considered applicable to corporations are the procedural safeguards included in the right to a free trial of article 6 ECHR. In that regard, it seems reasonable to consider that corporations cannot suffer coercion by public powers in the same condition as if they were individuals and, thus, corporate defendants deserve different (ie more reduced) protection. ${ }^{35}$ Indeed, from the perspective of the need of protection and the need to counterbalance public power and its exercise, we submit that creating 'corporate human rights' lacks a sufficient justification. ${ }^{36}$ If an alternative justification is sought in the concept of "due process" as a value in

\footnotetext{
${ }^{30}$ No matter how exceptionally, see Agrotexim v Greece, 330 ECtHR ser A3, 22-26, §§59-72 (1995) and M Emberland, 'The Corporate Veil in the Case Law of the European Court of Human Rights' (2003) ZaöR 63: 945969. However, this argument has been used also in support of the extension of human rights recognition to corporations, see I Aslam \& M Ramsdem, 'EC Dawn Raids: A Human Rights Violation?' (2008) The Competition Law Review 5(1): 61-87, 73.

${ }^{31}$ See E Poolman 'Reconceiving Corporate Personhood' (2011) Utah Law Review 4: 1629-1675: 1632-1639.

32 Dhooge, 'Human Rights for Transnational Corporations' (n 21) 227 ("corporations should not be equated to their human counterparts").

33 Id, 231 ("effective protection mandates that human rights be extended to transnational corporations in appropriate circumstances"). Indeed a similar solution has been adopted concerning article 8 ECHR, see M Emberland, 'Protection Against Unwarranted Searches and Seizures of Corporate Premises under article 8 of the European Convention of Human Rights: The Colas Est SA v. France Approach' (n7) 100 ("corporate premises enjoy a lower degree of protection than do the residences of individual persons"), though he excludes that differentiated scrutiny for article 6 or article 10 ECHR.

${ }^{34}$ A. Andreangeli, "Competition law and human rights: striking a balance between business freedom and regulatory intervention", in I. Lianos \& D. D. Sokol (eds), The Global Limits of Competition Law (Stanford U Press) 2012, 22-36 (ch. 2), 25.

${ }^{35}$ Along these lines, see Harding, Kohl \& Salmon, Human Rights in the Market Place (n 4) 233: 'both human and non-human or organisational actors may assert basic rights, but [...] their respective rights may not be of the same nature, and so may be said to have a different currency' (emphasis in the original).

${ }^{36}$ Similarly, see MacCulloch, 'The privilege against self-incrimination in competition investigations' (n 6) 234. Also, concerning the right to be free form self-incrimination, Dhooge, 'Human Rights for Transnational Corporations' (n 21) 240-241.
} 
itself (i.e., not as a human right), we acknowledge that there may be more scope to find justification in the need to design sound administrative procedures and to ensure high levels of good administration in the management of investigations and in the decision-making processes involved in the enforcement of economic law (and competition law in particular), but we would still disagree with the assimilation of those needs for regulatory quality and a need for 'corporate human rights'.

To put it more bluntly, in the field of the enforcement of economic law, administrative law procedures should be sound and there should clearly be a strong system of judicial review in place, but corporations should not have access to broader constitutional or human rights protections and any perceived shortcomings in the design and application of those procedures should remain within the sphere of regulatory reform. In the end, the design of the mechanisms of enforcement of economic law should be concerned with providing a workably sound framework, but should not strive to the same level of guarantees that were designed for criminal law investigations. The fact that corporations are the majoritarian (if not de facto exclusive) type of defendant in cases involving the enforcement of economic law seems to be an additional reason to justify the relaxation of those mechanisms in terms of procedural guarantees as compared to procedures where individuals are involved.

Indeed, we consider that there are good reasons to support this argument in the case law of the ECtHR concerned with the more reduced scope of guarantees to be provided in administrative law procedures (as compared to 'proper' criminal law investigations) and, more specifically, in competition law investigations. The following section looks more closely to these issues in the specific field of competition law enforcement.

\section{REASSESSING 'CORPORATE HUMAN RIGHTS' AND DUE PROCESS IN COMPETITION LAW ENFORCEMENT}

Given the (apparently) increasingly heftier fines imposed by the European Commission ${ }^{37}$ on the basis of articles 101 and 102 of the Treaty on the Functioning of the European Union (TFEU ${ }^{38}$ ), there are doubts that allegations of competition law infringements must be considered 'criminal charges' of sorts for the purposes of the ECHR - which, in principle, triggers the application of the due process guarantees envisaged in Article 6(1) ECHR. ${ }^{39}$ However, the situation is not that simple since, as hinted by the ECtHR in Jussila,

the evolution of the notion of a "criminal charge» has underpinned a gradual broadening of the criminal head to cases not strictly belonging to the traditional categories of the criminal law, for example [...] competition law [... which] differ from the hard core of criminal law [so that] the criminal-head guarantees will not necessarily apply with their full stringency ${ }^{40}$.

\footnotetext{
${ }^{37}$ See WPJ Wils, 'The Increased Level of EU Antitrust Fines, Judicial Review, and the European Convention on Human Rights' (2010) World Competition 33(1): 5-29; FR Agerbeek, 'EU antitrust fines and ECHR fair trial rights' (19 May 2010) echrblog.blogspot.co.uk/2010/05/eu-antitrust-fines-and-echr-fair-trial.html. 38 [2010] OJ C83/47.

39 This was first declared in Société Stenuit v France Series A no 232 (1992) 14 EHRR 509. Generally, see Harris, O'Boyle and Warbrick, Law of the European Convention on Human Rights, 2nd edn (OUP, 2009) 201-299.

40 Jussila v Finland App no 73053/01 (ECtHR, 23 November 2006). Cfr M Bronckers \& A Vallery, 'Business as usual after Menarini?' (2012) MLex Ab Extra 3(1): 44-7.
} 
Thus, there is an open question concerning the intensity and extent to which due process rights must be guaranteed in EU competition law enforcement and whether the current enforcement system complies with the 'less than fully stringent' requirements of Article 6(1) ECHR in 'non hard core criminal cases'.

According to the majority interpretation of Article 6(1) ECHR, the requirement for a 'fair and public hearing within a reasonable time by an independent and impartial tribunal established by law' must not necessarily be met at first instance when an administrative body reaches an initial decision imposing fines (even if they qualify as 'criminal charges' under the ECHR). The guarantees mandated by Article 6(1) ECHR will be (if not absolutely, sufficiently) upheld if such initial 'conviction' can be challenged before a body meeting the requirements of Article 6(1) ECHR that can review it on the merits, both in facts and in points of law. ${ }^{41}$

In our view, the ECtHR recognised in Jussila that a full transfer of the guarantees developed under Article 6(1) ECHR for 'pure' criminal proceedings to the field of competition law cases would be an excess in the interpretation and application of the Convention ${ }^{42}$. Following that (implicit) recognition of a risk of excessive extension of the guarantees recognised in Article 6(1) ECHR, and in view of the lack of a strong justification for the existence of such guarantees as '(corporate) human rights' proper (above \$2), it seems plausible to reconsider the extent and intensity of protection in competition law cases. ${ }^{43}$ Our proposal is to re-read the requirements of Article 6(1) ECHR to depart from the stringent position concerning hard-core criminal cases and to get closer to the requirements of Article 6(1) ECHR regarding administrative procedures (however less developed or consolidated they may be at this point in time), and then to acknowledge that those protections are actually attainable at the lower level of design of the enforcement and review procedures for competition law, without any actual need for the creation or recognition of 'corporate human rights' in this area. In our view, then, what is required in this area is, simply put, that decisions adopted in the application of competition law are open to sufficient judicial review by a body that has jurisdiction to quash the decision in case it identifies material errors in fact or law $w^{44}-i . e$. the standard applicable to administrative decisions.

A limitation on the viability of this 'light(er) judicial review' approach may be found in the fact that the ECtHR declared that 'on an application for judicial review, the courts do not review the merits of the decision but confine themselves to ensuring, in brief, that the authority did not act illegally, unreasonably or unfairly'. ${ }^{45}$ Indeed, in this same line of argument, it should be taken into consideration that as a matter of general due process requirements, the reviewing tribunal must

\footnotetext{
${ }^{41}$ A. Menarini Diagnostics S.r.l. c. Italie App no 43509/08 (ECtHR, 27 September 2011), para 59. Along the same lines, C Bellamy, 'ECHR and competition law post Menarini: An overview of EU and national case law' (July 2012) e-Competitions, No 47946, 2; and AE Beumer, 'The Interplay between Article 6 ECHR \& Article 47 Charter and the EU Competition Enforcement System-Is There a Need of 'Reviewing' the Standard of Review?', Working Paper presented at the Workshop 'A Europe of Rights: the EU and the ECHR', University of Surrey (8-9 June 2012).12-3.

${ }^{42}$ Contra, see Bellamy (n 41) 9.

${ }^{43}$ For discussion, see A Andreangeli, 'Between Economic Freedom and Effective Competition Enforcement: The Impact of Antitrust Remedies provided by the Modernisation Regulation on Investigated Parties' Freedom to Contract and to Enjoy Property' (2010) Competition Law Review 6(2): 225-7, 233-4.

${ }^{44}$ Similarly Harris, O'Boyle and Warbrick, Law of the European Convention on Human Rights (2009) 228-9.

${ }^{45}$ Weeks v UK Series A no 114 (1987); 10 EHRR 293.
} 
have 'jurisdiction to examine all questions of fact and law relevant to the dispute before $i t^{\prime}{ }^{46}$ However, in our view, such a restrictive approach would disregard the indications of the ECtHR itself in Jussila and would imply a full extrapolation of the guarantees developed under Article 6(1) ECHR for 'pure' criminal proceedings in their full stringency to this type of non-hardcore criminal cases, while (implicitly) also fully equating corporate defendants with individuals and, consequently, falling into an unadverted trap of ethical justification that should be avoided.

On the contrary, we think that the case law of the ECtHR offers support for such a 'light(er) judicial review' approach in the field of administrative decisions. It is worth stressing that the ECtHR has found that, where: i) the administrative body adopting the initial decision follows a procedure that sufficiently complies with due process guarantees (i.e. where the design of the enforcement procedure is sound) ${ }^{47}$, and ii) the decision involves a 'classic exercise of administrative discretion' or, in other words 'the issues to be determined [require] a measure of professional knowledge or experience and the exercise of administrative discretion pursuant to wider policy aims ${ }^{48}$; then, (mere) judicial review of the legality of the decision suffices, and a (full) right of appeal on the merits is not necessary ${ }^{49}$-always provided that the reviewing tribunal can effectively grant a remedy to the appellant if successful ${ }^{50}$, which includes the possibility of quashing the decision and remitting the case for a new decision ${ }^{51}$. Therefore, the ECtHR seems satisfied that a level of procedural soundness well below the stringent standards created by human rights protection in criminal cases involving individual defendants suffices to uphold the guarantees that corporate competition law defendants are entitled to. And we very much support such an approach, which should exclude this field from the area of 'corporate human rights' and simply stress the need to promote good administration by other (less extreme and possibly more effective) means of regulatory design (and, eventually, regulatory reform).

Moreover, the specificities of competition laws and their enforcement should also be taken into account in the proposed adaptation task of human rights recognition to corporations in different settings. Competition law has adapted and taken into account the singularities of corporations in setting the scope of application to them, e.g. by considering that the prohibition of article 101 TFUE does not apply to agreements among corporations that form an economic unit (i.e., subsidiaries). ${ }^{52}$ In a similar vein and strongly inspired in the deterrent aim of sanctions for violations of the competition prohibitions, groups of companies forming an economic unit may experience an extension of liability for the fines imposed on any of the affiliated companies, and even higher fines. ${ }^{53}$ The perception, highly sensitive in the US, that companies are sometimes treated particularly

\footnotetext{
${ }^{46}$ Terra Woningen v Netherlands 1996-VI; 24 EHRR 456, para 53.

${ }^{47}$ Bryan v UK Series A no 335 (1995); 21 EHRR 342, para 47.

${ }^{48}$ Tsfayo v UK App no 60860/00 (ECtHR, 14 November 2006)) para 46; see Wils (n 5), 23-4; and Beumer (n 39) 13-4 and 24-5.

${ }^{49}$ Zumtobel v Austria Series A no 268 (1993); 17 EHRR 116, para 32.

${ }^{50}$ Kingsley v UK 2002-IV GC; 33 EHRR 13.

${ }^{51}$ For further details on these issues and the balance between full rights of appeal and limited judicial review in the analysis of Article 6 guarantees in the area of challenges against administrative decisions, see Harris, O'Boyle and Warbrick (n 7) 229-32.

52 This is the "group privilege", case 32/65 Italy v Council \& Commission [1966] ECHR 189, 1407 et seq; case 48/69 Imperial Chemical Industries v Commission (ICI) [1972] ECR 619, ๆ134; case C-73/95P Viho v Commission [1996] ECR I-5457, 116 and case C-217/05 CEEEES [2006] ECR I-11987, १44.

${ }^{53}$ Through "parental liability", case C-97/08P, Akzo Nobel NV v Commission [2009] ECR I-8237, ๆ60-61.
} 
harshly by juries ${ }^{54}$-and, consequently, deserve some extended 'due process' protection, remarkably against excessive punitive damages sentences-does not really apply to competition law enforcement at the EU and Member State levels. In these scenarios, the vast majority of cases are decided by civil servants and public officials professionally trained to enforce competition law rules, whose decisions are subjected to judicial review. Here, the 'anti-company' rationale does not really hold-at least in its standard formulation.

All of these considerations and the possibility to completely exclude 'corporate human rights' litigation from the setting of enforcement of competition law would, in our view, be highly relevant and desirable. As we have just seen, in the particular case of competition law enforcement, the existence of due process guarantees concerning public powers actions introduces various requirements that investigations and decisions by competition authorities and courts need to meet. However, given the specificities of competition rules and the administrative nature of competition law enforcement, due process safeguards may need to be properly tailored (i.e. reduced) so as not to impede the effective enforcement of these rules (which is further discussed below §4). Indeed, the difficulties faced by public authorities in charge of public competition law enforcement in finding and punishing violations of competition rules heavily condition the investigation and sanctioning procedures they follow. A reasonable trade-off needs to be reached between the rights of any (corporate) defendant accused of breaching competition prohibitions and the effectiveness of competition law enforcement. It is not that due process protections should be ignored, but they need to be properly adjusted to the adequate level (which in our view, and this bears repeating, should remain below human rights protection).

In the EU, competition rules enshrined in TFEU articles 101 and 102 are aimed at ensuring a level playing field for undertakings operating in the market according to which anti-competitive actions are forbidden. Heavy administrative sanctions against violations of those rules are aimed at deterring them. It is true that the authorities in charge of enforcing TFEU articles 101 and 102 should act only when they have enough evidence on the existence of a violation, and any undertaking being investigated needs to be properly informed of why it is being subject to investigation and to be recognized the right to argue and defend against any accusation against it. However, given the difficulties authorities face in finding and proving the violations of competition prohibitions, the complex assessments they need to make, and the strategic advantages that infringing parties generally have, it is necessary to allow investigations to proceed with relatively lenient procedural guarantees and also to lower the standard of proof of violations ${ }^{55}$.

In our opinion, being distinct from criminal law enforcement, the administrative character of competition law enforcement necessarily alleviates the procedural rights of parties in these proceedings ${ }^{56}$. Defendants subject to investigations and sanctions for violations of competition prohibitions do not probably experience the same emotional weakness faced by those subject to

\footnotetext{
${ }^{54}$ See RJ MacCoun, 'Differential Treatment of Corporate Defendants by Juries: An Examination of the "DeepPockets" Hypothesis' (1996) Law \& Society Review 30(1): 121-162.

55 See A Scordamaglia, 'Cartel Proof, Imputation and Sanctioning in European Competition Law: Reconciling effective enforcement and adequate protection of procedural guarantees', (2010) Competition Law Review, 7(1) 5-52, 8. See also ibid, EU Cartel Enforcement: Reconciling Effective Public Enforcement with Fundamental Rights, International Competition Law Series 54, Kluwer Law International, August 2013.

${ }^{56}$ See Sanchez Graells (n 8).
} 
criminal prosecution ${ }^{57}$. The justifications are the same that have led the ECtHR to accept that competition authorities are granted some margin of discretion in conducting their investigations and in making an assessment of any behaviour infringing articles 101 and 102 TFEU, limiting judicial review to the proportionality and plausibility of the competition authorities' findings. ${ }^{58}$

In sum, a requirement of all due process guarantees is not needed, and much less to grant corporate antitrust defendants 'corporate human rights' protection. The recognition of all due process safeguards would hurt the effectiveness of competition law, by making very difficult its enforcement (§4). If all procedural guarantees required in criminal law enforcement are extended tout court to competition law enforcement, competition authorities would probably face unsurmountable problems to detect, prove and sanction violations of competition rules. It would also have a negative effect on human rights protection itself. The remainder of the paper explores these issues in some further detail.

\section{DIMINISHING THE EFFECTIVENESS OF BOTH COMPETITION LAW ENFORCEMENT AND HUMAN RIGHTS PROTECTION THROUGH (INFLATIING) 'CORPORATE HUMAN RIGHTS'}

As mentioned in passing, the effectiveness of competition law requires competition authorities to investigate those actions that might infringe articles 101 or 102 TFEU and, for them to do so effectively, they need to be empowered to sanction those undertakings that are proven to effectively have done so. In conducting their tasks, competition authorities face the difficulties of finding information and evidence of anti-competitive actions, and the need to carry out complex economic assessments. But they are experienced and well prepared to do so, and their decisions in punishing violations of those rules are crucial in deterring future anti-competitive actions.

Neither that fact-finding exercise nor the analysis of the facts by competition authorities are crystal-clear tasks, and introducing the full-set of guarantees and safeguards required by due process in criminal proceedings in favour of corporations subject to antitrust investigation would obstruct the conduct of competition authorities' investigation and assessment tasks. In order to allow investigations to proceed quickly and smoothly, lenient procedural guarantees should be applied. ${ }^{59}$ In the same vein, given the difficulties faced in finding $100 \%$ definitive evidence that a violation has occurred (as the wording of the prohibitions themselves clearly reveals) a lower standard of proof may be required to the competition authority..$^{60}$ Several interpretations and assessments can be

\footnotetext{
57 Indeed, one of the criteria followed by the ECtHR in setting the scope of article 6 is the severity of the penalty the person may be imposed and how it substantially affects the individual's situation. See Judgment of the ECtHR of 8 June 1976, Engel \& others v. The Netherlands, A22, ๆ81; Judgment of 20 October 1997, Serves v. France, 142 and Marttinen v. Finland, Appl. no. 19235/03 [2009].

58 Judgment of the ECtHR of 27 September 2011, Menarini Diagnostics S.R.L. v. Italy, Appl. N. 43509/08, ๆๆ6466. See also M Botta \& A Svetlicinii, 'The Standard of Judicial Review in EU Competition Law Enforcement and Its Compatibility with the Right to a Fair Trial Under the EU Charter of Fundamental Rights', in T Kerikmäe (ed.), Protecting Human Rights in the EU (Springer, 2014) 107-127, 119-122.

${ }^{59}$ Along the same lines, see MacCulloch, 'The privilege against self-incrimination in competition investigations' (n 6) 232, who clearly indicated that 'In the [EU] and UK, where the privilege [against self-incrimination] is most limited, this complexity of regulation and the seriousness of the harm suffered are the most potent arguments deployed to restrict the privilege'.

${ }^{60}$ Where the use of circumstantial evidence and presumptions is allowed, see F Castillo de la Torre, 'Evidence, Proof and Judicial Review in Competition Cases", in CD Ehlermann \& M Marquis, European Competition Law
} 
made of the same facts, and for that reason competition authorities should only be required to construct a sound and rigorous case concerning the behaviour subject to investigation analysing if it falls within the scope of articles 101 or 102 TFEU. The ECtHR has acknowledged the need to provide the necessary deference to such judgments that imply 'classic exercise of administrative discretion' or, in other words 'the issues to be determined [require] a measure of professional knowledge or experience and the exercise of administrative discretion pursuant to wider policy aims' (above §3). Therefore, subjecting competition law enforcement to excessively demanding standards of proof, or to compliance with excessive (and unnecessary) protections of 'corporate human rights', would end up diminishing the effectiveness of competition law enforcement.

Moreover, and from a clearly normative perspective, it seems to be worth stressing that the enforcement of competition law is clearly seen as a mechanism mainly aimed at either preventing or correcting (as quickly and to the extent possible) distortions and restrictions of competition in the markets so as to allow the market mechanisms to continue working properly as an intermediate objective towards achieving allocative and dynamic efficiency and, ultimately, as a tool to protect welfare and promote innovation. This being a fundamental normative element in the design of competition law enforcement, it has some clear implications. On the one hand, it requires that competition law enforcement is as speedy and flexible as possible. This is clearly seen in the design of flexible enforcement mechanisms (that tend to benefit corporate defendants willing to accept guilt or to cooperate with the competition authorities) such as the leniency and settlement mechanisms in place in most jurisdictions (and, clearly, in the EU). On the flip of the coin, it might also be necessary to ensure such speedy reaction and to provide enforcement decisions adopted by competition authorities (following the already sufficiently sound administrative procedures) with almost immediate effectiveness by minimising the risk of appeal (and, consequently, suspension of their effects) to the appropriate level. In this regard, creating a too broad and generous basis for challenge or appeal on the basis of the protection of 'corporate human rights' would be a significant element creating a reduced effectiveness of competition law enforcement-even if the decisions were eventually upheld and implemented (or, in clearer terms, time is actually gold in the implementation of enforcement decisions aimed at restoring competitive market situations, since a belated execution of the measures-possibly of those other than the imposition of fines, but also those to some extent-may render them ineffective or even inadequate in a changed market and competitive setting). Therefore, eliminating one tier of potential challenges and appeals (both in terms of legal basis and available jurisdictional forum) by preventing 'corporate human rights' litigation in the area of competition law would contribute to strengthen the effectiveness of the system.

Finally, in order to contextualise the prior considerations, it may be worth stressing that competition laws are one of the main regulatory instruments for the protection of the market economy itself. Only properly functioning markets can bring about the benefits of the free market paradigm and the prevention of distortions of competition are clearly focused on consumer protection (through preventing welfare losses) and consumer interest. But, even if consumer welfare is not recognised as the ultimate valid normative standard and a total or social welfare approach

Annual 2009: Evaluation of Evidence and its Judicial Review in Competition Cases (Portland: Hart Publishing 2010) accessible at http://www.eui.eu/Documents/RSCAS/Research/Competition/2009/2009-COMPETITIONCastillo.pdf) 24. 
(more lenient towards corporate manufacturers or suppliers) is adopted, competition laws still remain one of the fundamental safeguards of the free market economy. From this perspective, it seems clear that an excessive protection of corporate defendants in competition enforcement procedures by an overgrowth of 'corporate human rights' (and, more specifically, due process rights) is a self-defeating strategy. In these cases, the attribution of those rights to corporate defendants can only handcuff the (already limited, in terms of actual human and other resources) enforcement powers of competition authorities and, in the end, result in a diminished effectiveness of a system unable to properly protect (social) welfare in the market economy. ${ }^{61}$ In somewhat comic terms, it could be represented as a system where the 'human rights' pliers would be used to pull out the teeth of the competition watchdog-which would simply result in a toothless competition law system unable to bite corporations engaged in anticompetitive behaviour. This should be seen as an undesirable outcome, given the very strong public interest element implicit in competition law enforcement. $^{62}$

Moreover, it is important to stress that granting full 'corporate human rights' may create problems not only regarding competition law enforcement, but also in connection with the enforcement of (proper) human rights themselves, as the amount of litigation that could derive from the consolidation of such development does not seem to be negligible. As the ECtHR already clarified in some instances where it was confronted with significant threads of increased litigation (and following an implicit 'floodgates argument'), the ECHR 'is intended to guarantee not rights that are theoretical or illusory but rights that are practical and effective' ${ }^{63}$ Therefore, a preference for the investment of all available resources in the protection of those human rights with a clearer and sounder justification (i.e. those of individuals, see above §2) over a diversion towards the protection of lower raking corporate (non-human) rights should be stressed. ${ }^{64}$

Indeed, there seems to be no good reason to promote permissive rules and standards oriented towards a stronger protection of 'corporate human rights' in competition law cases because undertakings having been fined for breaches of competition law will always have a very strong (financial) incentive to challenge them before the relevant courts (i.e. both the ECtHR and, potentially, the CJEU) or, at least, to win some time by resorting to this additional review procedure. Therefore, there are high incentives for an excessive recourse to (if not an abuse of) the procedure for (corporate) human rights protection on the basis of spurious claims of insufficient coporate human rights protection in competition law cases. As a matter of system design, then, restrictions on the actual opportunities to bring an action before the ECtHR and the CJEU on the basis of human

\footnotetext{
${ }^{61}$ The same point is made by $\mathrm{R} \mathrm{H}$ Lande, 'Quick - Somebody call Amnesty International! Intel Says EU Antitrust Fine Violated Human Rights' (July 27, 2009) Federal Trade Commission: Watch, 746(9) available at http://ssrn.com/abstract=1446845.

${ }^{62}$ Along the same lines, see the reasoning followed by the CJEU in its Judgment of 21 September 1989 in case 46/87 Hoechst $v$ Commission [1989] ECR 2859. See also Harding, Kohl \& Salmon, Human Rights in the Market Place (n 4) 105-106.

${ }^{63}$ Artico v Italy Series A no 37 (1980); 3 EHRR 1 para 33.

${ }^{64}$ Emberland likewise notes in his study of corporations as human rights beneficiaries that corporations have less at stake in terms of vulnerability within the social order, suggesting that '[c]orporate human rights issues may be judged trivial when compared with alleged violations of an individual human being's dignity, security or participation in political life'; Emberland, The Human Rights of Companies (n 3) 154. A similar argument is raised by M L Stoll, 'Corporate Rights to Free Speech?', (2005) Journal of Business Ethics 58: 261-269.
} 
rights' protection arguments seems a proportionate and desirable counterbalance to such perverse incentives.

Moreover, and possibly from a more prosaic but also relevant perspective, the ECtHR (and the CJEU to some more limited extent, as it is already competent to hear challenges against enforcement decisions in competition law matters) should be aware of the potentially significant impact of those cases in their workload and the significant amount of resources needed to deal with such complex cases. Furthermore, at least the ECtHR would need to significantly expand its expertise in the area of competition law (and, more generally, of economic regulation) in order to properly appraise the applications submitted for its protection under the ECHR-and this could be disproportionate to protect 'theoretical' due process rights of corporate defendants.

\section{CONCLUSION: GOING OVERBOARD IN ‘CORPORATE HUMAN RIGHTS’ PROTECTION}

This paper has shown how the rationale for the creation and protection of human rights (including due process guarantees) for individuals does not translate well and does not provide a sufficient justification for the recognition and enforcement of 'corporate human rights'. Focussing in the area of competition law enforcement, it has explored the already accepted reduction of guarantees available to corporate defendants under the ECHR and has argued that it justifies the exclusion of such considerations from the 'corporate human rights' arena-so that it goes back to its more natural nesting as a matter of institutional design and regulatory reform (if necessary).

Additionally to the general lack of justification for the existence of 'corporate human rights', the paper has also stressed that their recognition in the area of competition law enforcement would jeopardise two very important goals, such as the effectiveness of competition rules and the effectiveness of (individuals) human rights protection itself. In view of all those preliminary conclusions, we can only submit again that, in our view, the current trend of recognition and protection of 'corporate human rights' in the area of competition law enforcement (but also more generally) is going overboard, is unjustified and undesirable. Consequently, we propose to stop and reverse this trend. 